\title{
Ammonia volatilization losses from urea coated with copper, boron, and selenium
}

\section{Perdas por volatilização de amônia de ureia com cobre, boro e selênio}

\author{
Letícia de Abreu Faria ${ }^{1 *}$; Felippe Hoffmann Silva Karp²; Marcos Canto Machado \\ Adibe Luiz Abdalla ${ }^{4}$
}

\section{Highlights:}

Urea exhibited a $50.32 \% \mathrm{~N}$ loss by volatilization.

Urea coated with $\mathrm{B}$ and $\mathrm{Cu}$ reduced $\mathrm{N}$ losses by volatilization.

Selenium added to the urea coating of $\mathrm{B}$ and $\mathrm{Cu}$ had no effect on $\mathrm{N}$ volatilization.

\begin{abstract}
Urea coated with copper and boron may be a vehicle for selenium fertilization in grazing systems to improve both forage and animal productivity, and consequently, the nutritional quality of milk and meat. Urea is the most often used form of $\mathrm{N}$ fertilizer in Brazil; however, it can experience high losses by volatilization, primarily in pastures with high amounts of senescent biomass. The goal of this study was to evaluate losses by ammonia volatilization from urea coated with $\mathrm{Cu}, \mathrm{B}$, and $\mathrm{Se}$. The fertilizer was applied to the soil surface under forage straw residues in cylindric glass chambers under controlled laboratory conditions. The treatments were urea (UR), urea coated with boric acid and copper sulfate (UBC), urea coated with boric acid, copper sulfate, and selenium (UBCS), and ammonium sulfate (AS). Measurements were recorded at regular intervals after fertilizer application for 27 days. High losses occurred from ammonia volatilization of amidic-N sources in the initial days after fertilizer application. The total loss of $\mathrm{N}$ by ammonia volatilization according to fertilizer treatment was $\mathrm{UR}>\mathrm{UBC}=\mathrm{UBCS}$ $>$ AS. Urea lost by ammonia volatilization accounted for up to $50 \%$ of the $\mathrm{N}$ applied, although losses from coated urea treatments UBC and UBCS were $11.45 \%$ lower than that of urea. The $\mathrm{Cu}$ and $\mathrm{B}$ in the coated urea reduced losses by ammonia volatilization and the inclusion of Se had no effect. It is suggested that $\mathrm{Se}$ may be added to the $\mathrm{Cu}$ and $\mathrm{B}$ coating of urea to reduce ammonia volatilization.
\end{abstract}

Key words: Biofortification. Pasture. Sodium selenate. Straw residue.

\section{Resumo}

O revestimento de ureia com $\mathrm{Cu}$ e $\mathrm{B}$ pode ser um veículo para a adubação com selênio (Se) em pastagens melhorando a produtividade da forragem e animal e, consequentemente a

\footnotetext{
1 Prof ${ }^{\mathrm{a}}$, Universidade Federal Rural da Amazônia, UFRA, Campus Paragominas, Paragominas, PA, Brasil. E-mail: leticiadeabreufaria@gmail.com

2 Discente, Escola Superior de Agricultura Luiz de Queiroz, Universidade de São Paulo, ESALQ/USP, Piracicaba, SP, Brasil. E-mail: felippe.karp@usp.br

3 Prof., Fundação Indaiatubana de Educação e Cultura, FIEC, Indaiatuba, SP, Brasil. E-mail: marcosiq@gmail.com

4 Prof., Centro de Energia Nuclear na Agricultura, Universidade de São Paulo, CENA/USP, Piracicaba, SP, Brasil. E-mail: abdalla@cena.usp.br

* Author for correspondence
} 
qualidade nutricional de leite e carne. A ureia é a fonte de $\mathrm{N}$ mais utilizada no Brasil, porém pode apresentar elevadas perdas por volatilização, principalmente em pastagens com altas quantidades de biomassa senescente. $\mathrm{O}$ objetivo foi avaliar as perdas por volatilização de amônia em ureia revestida com $\mathrm{Cu}, \mathrm{B}$ e $\mathrm{Se}$ aplicado em superfície sob resíduos de palhada de forragem em câmaras cilíndricas de vidro sob condições controladas em laboratório. Os tratamentos foram ureia revestida com ácido bórico e sulfato de cobre (UBC), ureia revestida ácido bórico, sulfato de cobre e selênio (UBCS), e sulfato de amônio (AS) e medidas nos dias após aplicação dos fertilizantes. Altas perdas por volatilização de amônia a partir das fontes amídicas ocorreram nos primeiros dias após a aplicação dos fertilizantes. As perdas totais de $\mathrm{N}$ por volatilização de amônia comparando os fertilizantes foi de $\mathrm{UR}>\mathrm{UBC}=\mathrm{UBCS}>\mathrm{AS}$. A ureia perdeu amônia por volatilização em até $50 \%$ do $\mathrm{N}$ aplicado, enquanto as perdas com as ureias revestidas UBC e UBCS foram $11,45 \%$ menores que a ureia. O $\mathrm{Cu}$ e o $\mathrm{B}$ no revestimento da ureia reduzem as perdas por volatilização de amônia e a inclusão do Se não apresenta influência.

Palavras-chave: Biofortificação. Pastagem. Selenato de sódio. Palhada.

Selenium application along with fertilizer is an agricultural process for biofortification that has been proposed as a strategy to increase the dietary Se intake for animals and humans (Wu et al., 2015). The consumption of Se-fertilized forage provides better incorporation into ruminal microorganisms (Galbraith et al., 2015), consequently promoting higher concentration in animal muscle and milk (Davis et al., 2008). Selenium along with urea at doses of 20 to $80 \mathrm{~g} \mathrm{ha}^{-1}$ yielded positive effects in increasing Se content and truly degraded organic matter in vitro of Brachiaria brizantha 'Marandu' (Faria et al., 2018).

Urea is the most widely used nitrogen source to improve productivity of pastures, primarily because of its low cost; however, it has a high susceptibility to ammonia losses by volatilization depending on factors, such as the management and condition of soil moisture, temperature, soil $\mathrm{pH}$, wind velocity, soil organic carbon and $\mathrm{N}$, and even the rate of N-urea application.

Losses by ammonia volatilization occurred on the initial days after $\mathrm{N}$ fertilizer side dressing (Cancellier et al., 2016) reaching $94 \%$ by day 14 (Faria, Nascimento, Vitti, Luz, \& Guedes, 2013; Oliveira, Gava, Vitti, Bendassoli, \& Trivelin, 1997) when applied to a straw-covered soil surface. This occurs because the urea granule does not rapidly diffuse into the surrounding soil (Fenn \& Richards, 1986); consequently, urea is hydrolyzed by urease on the soil surface.

Urease is an enzyme produced by microorganisms that accumulates in soil colloids and organic substances resulting in high activity (Paulson \& Kurtz, 1969); that is affected by vegetation type (Longo \& Melo, 2005). UBC has shown potential in the reduction of the volatilization loss of ammonia (Faria et al., 2013). Some chemical elements, including trace elements, have potential as urease inhibitors (Tabatabai, 1977). The use of urease inhibitors to coat urea grains could aid in increasing the efficient use of this $\mathrm{N}$ source by avoiding losses by volatilization (Chagas, Gouveia, Costa, Barbosa, \& Alves, 2017).

Nitrogen fertilization of pastures is a method to increase beef productivity in Brazil; as well as a possible vehicle to increase Se content in forage. Hence, the goal of this study was to evaluate the losses by ammonia volatilization from urea coated with $\mathrm{Cu}, \mathrm{B}$, and $\mathrm{Se}$ applied to the soil surface under forage straw residues.

The research was conducted in volatilization chambers under controlled laboratory conditions (Soares, Cantarella, \& Menegale, 2012) in a 
complete randomized block experimental design in a factorial scheme of $4 \times 11$ with eigth replicates. The treatments were urea (UR), urea coated with boric acid and copper sulfate (UBC), urea coated with boric acid, copper sulfate, and selenium (UBCS), and ammonium sulfate (AS) and measurements were recorded at 1, 2, 3, 4, 7, 9, 11, 14, 17, 21, and 27 days after fertilizer application.

The experimental unit was comprised of a cylindric glass chamber with a basal area of 100 $\mathrm{cm}^{2}$ containing $1.3 \mathrm{~kg}$ of dry soil. A control without $\mathrm{N}$ was conducted under the same conditions during the experimental period and served as a correction factor in the calculation of ammonia losses from fertilizer, as measured by ammonia collectors.

The soil was collected from the $0-0.2 \mathrm{~m}$ top layer of a sandy loam soil classified as Typic Hapludox at Piracicaba-SP, Brazil. Soil characterization was $180 \mathrm{~g} \mathrm{~kg}^{-1}$ clay, $20 \mathrm{~g} \mathrm{~kg}^{-1}$ silt, and $800 \mathrm{~g} \mathrm{~kg}^{-1}$ sand;

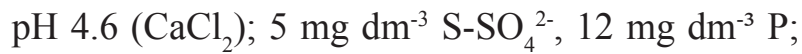
$0.3 \mathrm{mmolc} \mathrm{dm}^{-3}$ of $\mathrm{K} ; 10$ mmolc dm $\mathrm{dm}^{-3} \mathrm{Ca} ; 8$ mmolc $\mathrm{dm}^{-3} \mathrm{Mg} ; 38$ mmolc dm ${ }^{-3} \mathrm{H}+\mathrm{Al} ; 0$ mmolc $\mathrm{dm}^{-3} \mathrm{Al}$. The cation-exchange capacity was $56.3 \mathrm{mmolc} \mathrm{dm}^{-3}$ and base saturation was $33 \%$. Other characteristics included $0.24 \mathrm{mg} \mathrm{dm}^{-3} \mathrm{~B}, 0.6 \mathrm{mg} \mathrm{dm}^{-3} \mathrm{Cu}, 97 \mathrm{mg}$ $\mathrm{dm}^{-3} \mathrm{Fe}, 7.9 \mathrm{mg} \mathrm{dm}^{-3} \mathrm{Mn}, 1.4 \mathrm{mg} \mathrm{dm}^{-3} \mathrm{Zn}$, less than $4 \mathrm{mg} \mathrm{dm}^{-3} \mathrm{Na}$, and a low Se level $\left(0.5 \mathrm{mg} \mathrm{dm}^{-3}\right)$.

The soil was limed with $2 \mathrm{Mg} \mathrm{CaCO}_{3} \mathrm{ha}^{-1}$ equivalents and its surface was covered with $4.4 \mathrm{~g}$ straw residues of Brachiaria brizantha containing senescent leaves, stems, and sheaths corresponding to $442 \mathrm{~g} \mathrm{~m}^{-2}$ as measured under natural conditions in a rotational grazing system. The soil was moistened to $60 \%$ of the maximum water retention capacity for an incubation period of 10 days to recompose the microbial and enzymatic activities prior to the application of the fertilizer treatments.
The coating fertilizers were prepared using a precision scale balance. Prior to coating, a mixture of boric acid and copper sulfate was prepared to supply $0.4 \mathrm{~g} \mathrm{~kg}^{-1} \mathrm{~B}$ and $0.14 \mathrm{~g} \mathrm{~kg}^{-1} \mathrm{Cu}$ (Faria et al., 2013). Treatment with Se was prepared with sodium selenate added into the mixture of $\mathrm{Cu}$ and B. All mixtures were homogenized with a mortar and pestle before coating the urea granules (average weight of granules $8.9 \mathrm{mg}$ ). Quantities of $\mathrm{N}$ and $\mathrm{Se}$ were calculated in equivalence to the chamber area surface with the application of $34.5 \mathrm{~g} \mathrm{Se} \mathrm{ha}^{-1}$ (Faria et al., 2018) and $100 \mathrm{~kg} \mathrm{~N} \mathrm{ha-1.}$

The fertilizer treatments were applied to the surface of the straw residues. Volatilized ammonia was swept and transferred to a flask containing a boric acid solution to trap the gas. It was then measured by titration with a standardized $\mathrm{H}_{2} \mathrm{SO}_{4}$ solution (Cantarella \& Trivellin, 2001).

Data obtained were subjected to statistical analysis using $\mathrm{SAS}^{\circledR}$ v.9.2 (Statistical Analysis System Institute, Cary NC, USA). Fertilizers and measurement dates were used as fixed effects in the analysis of variance (ANOVA). Significant effects of fertilizer treatments were compared using orthogonal contrasts and the Tukey's test with a 5\% level of significance.

Uniform fertilization with urea coated with sodium selenate was attained with no influence of Se on losses by ammonia volatilization (Table 1). The AS treatment was used as a standard because of its stability under experimental conditions, whereas $\mathrm{N}$ amidic from urea showed large $\mathrm{N}$ losses by ammonia volatilization. The urea treatment lost up to $50 \%$ of applied $\mathrm{N}$ by ammonia volatilization. Losses of $\mathrm{N}$ from coated urea fertilizer UCB and UCBS were $11.45 \%$ lower than that of urea. 
Table 1

Orthogonal contrasts and significance of total volatilized $\mathrm{N}-\mathrm{NH}_{3}$

\begin{tabular}{lc}
\hline Treatments & $\begin{array}{c}\mathrm{N}^{-N_{3}} \text { volatilized } \\
\mathrm{mg} \mathrm{vessel}^{-1}(100 \mathrm{mg} \text { of N applied })\end{array}$ \\
\hline Ammonium Sulfate (AS) & 1.38 \\
Urea (UR) & 50.32 \\
Urea coated with B and Cu (UBC) & 38.73 \\
Urea coated with B, Cu, and Se (UBCS) & 38.99 \\
CV $(\%)$ & 26 \\
\hline Contrasts & F Test \\
\hline AS vs UR + UBC + UBCS & $-41.29^{* *}$ \\
UR $v$ UBC + UBCS & $11.45^{* *}$ \\
UBC $v$ UBCS & $-0.26^{\mathrm{ns}}$ \\
\hline
\end{tabular}

ns: non-significant; * and $* *$ : significant at $5 \%$ and $1 \%$ by the $\mathrm{F}$ test, respectively.

The total loss of $\mathrm{N}$ by ammonia volatilization comparing the fertilizers was $\mathrm{UR}>\mathrm{UBC}=\mathrm{UBCS}>$ AS. Amidic-N sources (e.g., urea) had higher losses of $\mathrm{N}$ than did AS, whereas coated urea with urease inhibitors showed intermediate losses. The reduction of ammonia losses by volatilization from urea by B and $\mathrm{Cu}$ have been previously observed (Faria et al., 2013), because of the potential of metals to function as a urease inhibitor (Tabatabai, 1977). Similarly, Se was a potential inhibitor for urease activity; however, its inhibition was observed only for doses of Se greater than those utilized in this experiment, which could be harmful to grazing animals.

Higher losses of ammonia volatilization from amidic- $\mathrm{N}$ sources were observed in the initial days after fertilizer application, and urea exhibited high peaks through the $4^{\text {th }}$ day (Figure 1). The curve of losses by ammonia volatilization in amidic-N sources decreased and were similar from the $7^{\text {th }}$ day to the $21^{\text {st }}$ day, reaching nearly zero by day 27. Urea losses by ammonia volatilization were at $96.7 \%$ of the total amount of ammonia volatilized within the first 7 days (Cancellier et al., 2016). The experimental environment provided favorable conditions for ammonia volatilization, primarily in the initial days after $\mathrm{N}$ fertilization. The straw residues on the soil surface were favorable for urease activity. Furthermore, the insufficient humidity hampered the rapid incorporation of fertilizer, allowing the higher and continuous losses from amidic-N sources, mainly from urea with no urease inhibitor. Low water content in the soil increased the losses by ammonia volatilization because of the higher content of ammonium and nitrate in the solution were favorable for gas formation from the ammonia (Silva et al., 2017). 


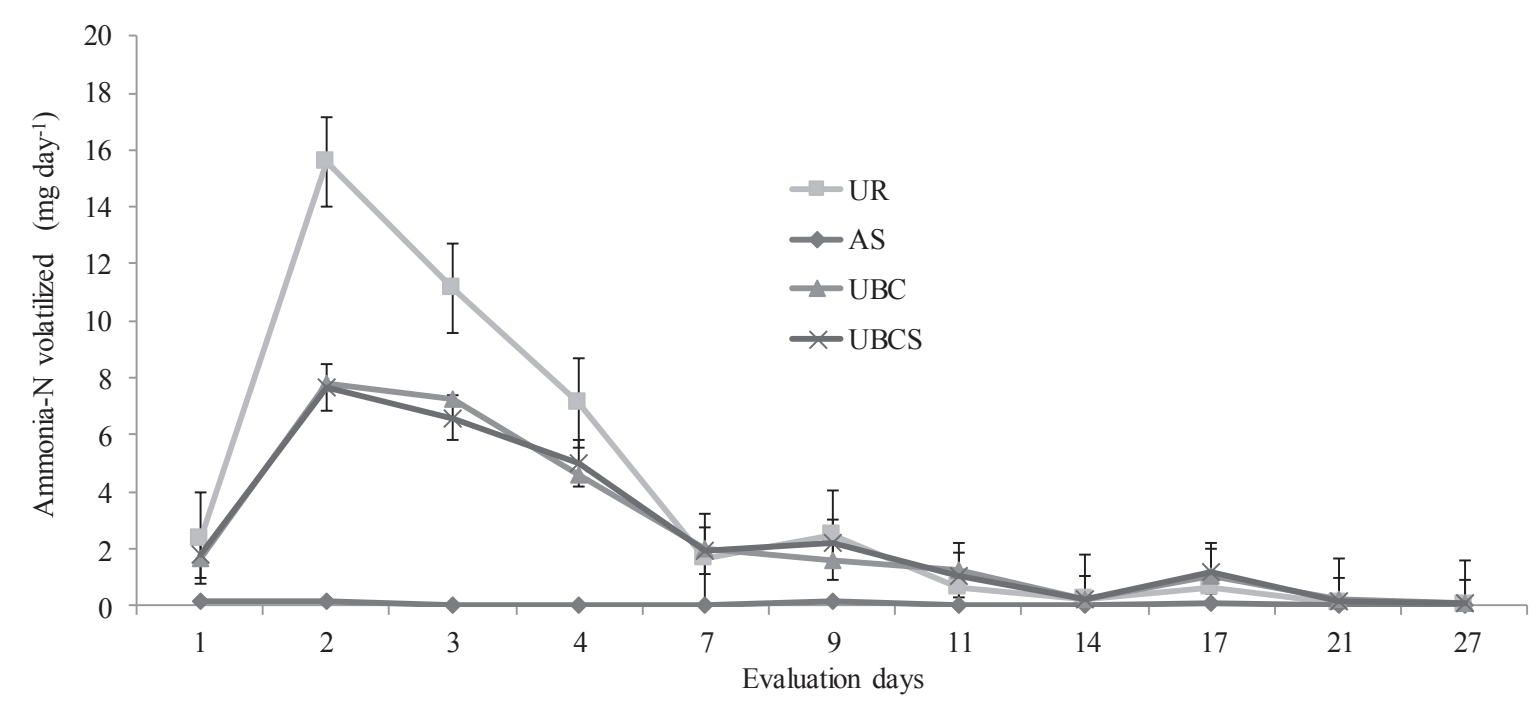

Figure 1. Ammonia volatilization losses as a function of days after fertilization. UR: urea, AS: ammonium sulfate, UBC: urea coated with boric acid and copper sulfate; UBCS: urea coated with boric acid, copper sulfate, and sodium selenite.

Soil surface in pastures is covered by large amounts of senescent biomass along with losses during the grazing period, even with the utilization of efficient management systems. Therefore, the presence of the senescent plant biomass negatively affects soil fertilizer incorporation, as well as proportionates a high urease activity, which consequently increases the losses of amidic-N sources by ammonia volatilization. However, rainfall of more than $50 \mathrm{~mm}$ reduces volatilization losses to almost zero, even in no tillage systems (Nascimento, Vitti, Faria, Luz, \& Mendes, 2013). $\mathrm{Cu}$ and $\mathrm{B}$ in the coating of urea also reduced losses by ammonia volatilization, while the Se inclusion had no effect on ammonia volatilization.

\section{Acknowledgments}

The authors would like to thank Maria R.S.R. Peçanha and the staff of the Animal Nutrition Laboratory (LANA/CENA-USP) for all their technical support and analyses. This research was financially supported by the National Counsel of Technological and Scientific Development (CNPq).

\section{References}

Cancellier, E. L., Silva, D. R. G., Faquin, V., Gonçalves, B. A., Cancellier, L. L., \& Spehar, C. R. (2016). Ammonia volatilization from enhanced-efficiency urea on notill maize in Brazilian cerrado with improved soil fertility. Ciência e Agrotecnologia, 40(2), 133-144. doi: 10.1590/1413-70542016402031115

Cantarella, H., \& Trivelin, P. C. O. (2001). Determinação de nitrogênio inorgânico em solo pelo método da destilação a vapor. In B. Van Raij, J. C. Andrade, H. Cantarella, \& J. A. Quaggio (Eds.), Análise química para avaliação da fertilidade de solos tropicais (pp. 271-276). Campinas: Instituto Agronômico.

Chagas, P. H. M., Gouveia, G. C. C., Costa, G. G. S., Barbosa, W. F. S., \& Alves, A. C. (2017). Volatilização de amônia em pastagem adubada com fontes nitrogenadas. Revista de Agricultura Neotropical, 4(2), 76-80. doi: 10.32404/rean.v4i2.1301

Davis, P. A., Mcdowell, L. R., Wilkinson, N. S., Buergelt, C. D., Van Alstyne, R., Weldon, R. N.,... MatsudaFugisaki, E. Y. (2008). Comparative effects of various dietary levels of Se as sodium selenite or Se yeast on blood, wool, and tissue Se concentrations of whether sheep. Small Ruminant Research, 74(1-3), 149-158. doi: 10.1016/j.smallrumres.2007.05.003

Faria, L. A., Karp, F. H. S., Righeto, P. P., Abdalla, A. L., Fo., Lucas, R. C., Machado, M. C.,... Abdalla, A. L. (2018). Nutritional quality and organic matter 
degradability of Brachiaria spp. agronomically biofortified with selenium. Journal of Animal Physiology and Animal Nutrition, 102(6), 14641471. doi: 10.1111/jpn.12971

Faria, L. A., Nascimento, C. A. C., Vitti, G. C., Luz, P. H. C., \& Guedes, E. M. S. (2013). Loss of ammonia from nitrogen fertilizers applied to maize and soybean straw. Revista Brasileira de Ciências do Solo, 37(4), 969-975. doi: 10.1590/S0100-06832013000400014

Fenn, L. B., \& Richards, J. (1986). Ammonia loss from surface applied urea-acid products. Fertilizer Research, 9(3), 265-275. doi: 10.1007/BF01050352

Galbraith, M. L., Vorachek, W. R., Estill, C. T., Whanger, P. D., Bobe, G., Davis, T. Z., \& Hall, J. A. (2015). Rumen microorganisms decrease bioavailability of inorganic selenium supplements. Biological Trace Element Research, 171(2), 338-343. doi: 10.1007/ s12011-015-0560-8

Longo, R., \& Melo, W. J. (2005). Atividade da urease em latossolos sob influência da cobertura vegetal e da época de amostragem. Revista Brasileira de Ciências do Solo, 29(4), 645-650. doi: 10.1590/ S0100-06832005000400017

Nascimento, C. A. C., Vitti, G. C., Faria, L. A., Luz, P. H. C., \& Mendes, F. L. (2013). Ammonia volatilization from coated urea forms. Revista Brasileira de Ciências do Solo, 37(4), 1057-1063, doi: 10.1590/ S0100-06832013000400022
Oliveira, M. W., Gava, G. J. C., Vitti, G. C., Bendassoli, J. A., \& Trivelin, P. C. O. (1997). Volatilização de amônia proveniente da ureia $\left({ }^{15} \mathrm{~N}\right)$ aplicada em um solo cultivado com cana-de-açúcar. Anais do Encontro Científico dos Pós-Graduandos do CENA/ USP, Piracicaba, SP, Brasil.

Paulson, K. N., \& Kurtz, L. T. (1969). Locus of urease activity in soil. Soil Science Society of American Procedure, 33(6), 897-901. doi: 10.2136/ sssaj1969.03615995003300060029x

Silva, D. F., Pegoraro, R. F., Maia, V. M., Kondo, M. K., Souza, G. L. O. D., \& Mota, M. F. C. (2017). Volatilização de amônia do solo após doses de ureia com inibidores de urease e de nitrificação na cultura do abacaxi. Revista Ceres, 64(3), 327-335. doi: $10.1590 / 0034-737 \times 201764030014$

Soares, J. R., Cantarella, H., \& Menegale, M. L. C. (2012). Ammonia volatilization losses from surfaceapplied urea with urease and nitrification inhibitors. Soil Biology and Biochemistry, 52, 82-89. doi: 10.1016/j.soilbio.2012.04.019

Tabatabai, M. A. (1977). Effects of trace elements on urease activity in soils. Soil Biology and Biochemistry, 9(1), 9-13. doi: 10.1016/0038-0717(77)90054-2

Wu, Z., Bañuelos, G. S., Lin, Z. Q., Liu, Y., Yuan, L., Yin, X., \& Li, M. (2015). Biofortification and phytoremediation of selenium in China. Frontiers in Plant Science, 6, 1-8. doi: 10.3389/fpls.2015.00136 